\title{
Peertechz
}

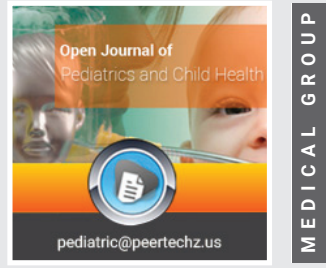

\section{Study of the role of IQ in children with Enterobius vermicularis infestation} compared to healthy children

\author{
Soudabeh Etemadi ${ }^{1,2 \star}$ and Hosniehoseini ${ }^{3}$ \\ ${ }^{1}$ Infectious Diseases and Tropical Medicine Research Center, Resistant Tuberculosis Institute, \\ Zahedan University of Medical Sciences, Zahedan, Iran \\ ${ }^{2}$ Department of Medical Parasitology and Mycology, Faculty of Medicine, Zahedan University of \\ Medical Sciences, Zahedan, Iran
}

${ }^{3}$ Department of Laboratory Sciences, Zahedan Branch, Islamic Azad University, Zahedan, Iran
Received: 13 July, 2021

Accepted: 20 July, 2021

Published: 21 July, 2021

*Corresponding author: Dr. Soudabeh Eetemadi, Department of Medical Parasitology and Mycology, Faculty of Medicine, Zahedan University of Medical Sciences, Zahedan, Iran, Email: ssetemadi@gmail.com

Keywords: Enterobius vermicularis; IQ; Children's intelligence test; Healthy children

https://www.peertechzpublications.com

\section{Check for updates}

\section{Abstract}

Background: Enterobius vermicularis has the widest geographic distribution among parasitic worms. This parasitic infestation is more common among children in population centers (nursery school, preschool). These parasites can affect the mental performance of children. This study investigated the role of IQ in children infestation with E.vermicularis were compared with healthy children in child care centers in Zahedan.

Materials and methods: This descriptive study on 425 (218 boys- 207 girls) 3-10 years samples form three different geographical (North- south and center) were randomly selected. Scotch Tape Test was used to check for contamination with E.vermicularis. The Draw-a-Man test was used to study IQ in children. 30 children infestation with the parasite were selected as case group and 30 healthy children were selected as control group. Data were analyzed using SPSS software version 20 and pair sample T Test.

Results: Prevalence of infestation was $7 / 5 \%$. Average IQ scores in the control group was 106 and in patients' group was $104 / 5$. The highest rate of infestation in children with average intelligence factor was 15(50\%). Children with high IQ was the low rate of infestation 2 (6\%) and showed no significant relation between 2 group in Average IQ scores ( $P V \geq 0.05=0.2)$. The highest rate of infestation was in the southern region (15 case).

Conclusion: The mental performance of children in group control was improve and recommended affect cure E. vermicularis in mental performance of children.

\section{Background}

Enterobius vermicularis (needle worm, thread worm or chair worm) is one of the nematode worms that has more geographical distribution than other worms [1]. It is estimated that at least 200 million people worldwide, especially children, are infected each year [2]. The prevalence of E. vermicularis infestation is associated with poor environmental hygiene, inadequate personal hygiene, and contaminated food [3].

Numerous studies have been performed on the relationship between the prevalence of $E$. vermicularis in children with sex, age, demographic and geographical factors, blood and immunological factors [2]. However, psychological and IQ tests in children have not been performed.

The Draw-a-Man test is one of the easiest, most practical and universal visual tests that is used to determine the degree of intelligence of the child's mental age and IQ and we want to reach a conclusion about the child's IQ as soon as possible [4]. The aim of this study was to compare the IQ of children with $E$. vermicularis infestation in comparison with healthy children by a simple Draw-a-Man test. 


\section{Materials and methods}

\section{Sample study and microscopic examination}

A cross-sectional study was conducted on 425 children (310 years). samples form three different geographical (Northsouth and center) Zahedan southwest in IRAN were randomly selected. Cellophane tape samples were taken from participants The adhesive tape was pressed on the anal area and around it several times in different directions and then labeled on the glass slide. This procedure was performed by mothers of children in the morning and evening and defecation, using the toilet or taking bath. The cellophane tape samples were examined microscopically by a parasitologist in the laboratory of Islamic Azad University of Zahedan with light microscope.

\section{The Draw-a-Man test and to score}

The Goodenough-Harris Drawing test was a projective personality test used for clinical purposes and intelligence testing. Children participating were asked to draw three pictures, one of a man, a woman, and of themselves. The drawings were then evaluated using 64 scoring items. A score is assigned to each component of Draw-a-Man if drawn by the child. The given scores are added together and then, using a special table (tables test), the raw score is converted to mental age and then obtained by the IQ formula [5].

\section{Data entry and statistical analysis}

Data were collected and then entered in SPSS 20 statistical software and pair sample T Test was used to compare IQ in case and control groups. $\mathrm{P} \leq 0.05$ was considered statistically significant.

\section{Results}

Of the 425 -cellophane tape, $7.52 \%$ (32/425) samples of E. vermicularis were detected by microscopic examination. However, the frequency of infestation among girls was higher than that among boys at rates of $8.17 \%(17 / 208)$ and $6.91 \%$ $(15 / 217)$, respectively. Statistically, no significant $(P>0.05)$ difference in infestation rate was recorded between girls and boys with enterobiasis. The highest infestation was reported in the age group of 7-10 years with a rate of $9.04 \%$. Statistically non-significant $(\mathrm{P}>0.05)$ differences were observed among age groups concerning enterobiasis (Table 1).

The mean IQ scores were 106 in the control group and 104.5 in the group of children with E. vermicularis. The highest rate of accessory infestation was seen in children with moderate IQ (50\% (15 cases)) and in children with high IQ (genius) had the lowest rate of infection ( 2 cases $(6 \%)$ ) and results showed

Table 1: Prevalence of $E$. vermicularis among children in relation to age group.

\begin{tabular}{|c|c|c|c|c|c|}
\hline $\begin{array}{c}\text { Age } \\
\text { groups }\end{array}$ & $\begin{array}{c}\text { Total } \\
\text { examinations }\end{array}$ & Gender & $\begin{array}{c}\text { Negative } \\
\text { enterobiasis }\end{array}$ & $\begin{array}{c}\text { Positive } \\
\text { enterobiasis }\end{array}$ & $\begin{array}{c}\text { Total no. } \\
(\%)\end{array}$ \\
\hline $3-6$ & 196 & girl & 88 & 7 & $13(6.63)$ \\
\hline \multirow{2}{*}{$7-10$} & 229 & boy & 95 & 6 & 19 \\
\hline total & 425 & girl & 103 & 10 & $19.04)$ \\
\hline & & boy & 107 & 32 & $32(7.52)$ \\
\hline
\end{tabular}

no significant relation between 2 group in average IQ scores $(\mathrm{PV} \geq 0.05=0.2)$ ). Based on the samples collected from the north, center and south of Zahedan, positive cases of 7, 10 and 15 were reported, respectively. The highest rate of enterobiasis infestation was in the southern region (15 case).

\section{Discussion}

Children are among the population groups most infected with parasites. They are usually asymptomatic carriers and can increase the prevalence of parasites and cause health problems [6]. In the present study, the rate of parasitic infection among children aged 3-10 years was 7.5\% and mean IQ scores were 106 in the control group and 104.5 in the group of children with E. vermicularis.

Most children start their painting by Draw-a-Man. This drawing is easy and attractive for children, and from this simple drawing, the level of intelligence of the child can be understood Another advantage of such a test is that it is applicable from the age of 3 to 13 and is also useful for children who are unable to speak or do not know the language and the test does not take much time. Knowing your child's level of intelligence and consulting with a child psychologist will help your child get on the right track in life. Expectations should be commensurate with his or her level of intelligence and his or her tastes and abilities. It is even possible to improve the child's intelligence $[7,8]$.

Symptoms of E. vermicularis include anal itching, burning sensation in the sitting area, sleep disturbance, fatigue, restlessness and anger [9]. These symptoms can affect a child's intelligence and senses [10]. Other symptoms, such as bruxism or tooth decay due to stress and nightmares, can upset a child and have a devastating effect on his or her mental functioning.

This study showed that IQ scores were slightly higher (IQ scores $=106$ ) in healthy children than in children with infestation E. vermicularis. To conclude, more studies should be done with different IQ tests. but according to the results of treatment of E. vermicularis infection for better mental function in children is recommended.

\section{References}

1. Fan CK, Chuang TW, Huang YC, Yin AW, Chou CM, et al. (2019) Enterobius vermicularis infection: prevalence and risk factors among preschool children in kindergarten in the capital area, Republic of the Marshall Islands. BMC Infect Dis 19: 536. Link: https://bit.ly/3eDx91B

2. Al-Daoody AAK, Al-Bazzaz ENH (2020) Impact of Enterobius vermicularis infection on biochemical parameters in the blood of children in Erbil Province, Iraq. BMC Infect Dis 20: 336. Link: https://bit.ly/2UYbQ3Q

3. Feiz Haddad MH, Kord E, Rafiei A, Feiz Haddad R (2014) A Study on the Prevalence of Enterobius vermicularis in Kindergartens of Dezful City (Khuzestan Province, Iran), 2013. Journal of Medical Microbiology and Infectious Diseases 2: 76-79. Link: https://bit.ly/3rnAlyb

4. Floyd RG, Farmer RL, Schneider WJ, McGrew KS (2021) Theories and measurement of intelligence. Link: https://bit.ly/36MN5u5

5. Goodenough FL (1926) A new approach to the measurement of the intelligence of young children. The Pedagogical Seminary and Journal of Genetic Psychology 33: 185-211. Link: https://bit.ly/3kAm4SJ 
6. Hama AA, Rahemo ZI (2014) Intestinal parasitosis in relation to haemoglobin concentration among primary schoolchildren in erbil province kurdistan-iraq. International Science Journal 1: 96-99. Link: https://bit.ly/2V1ILo0

7. Colom R, Flores-Mendoza CE, Abad FJ (2007) Generational changes on the Draw-a-Man test: A comparison of Brazilian urban and rural children tested in 1930, 2002 and 2004. J Biosoc Sci 39: 79-89. Link: https://bit.ly/3xUyvg1

8. Chen-Sea MJ (2000) Validating the Draw-A-Man Test as a personal neglect test. Am J Occup Ther 54: 391-397. Link: https://bit.ly/3ivowXY
9. Alemu G, Abossie A, Yohannes Z (2019) Current status of intestinal parasitic infections and associated factors among primary school children in Birbir town, Southern Ethiopia. BMC Infect Dis 19: 1-8. Link: https://bit.ly/3BohM6Q

10. Al-Qadhi BN, Al-Warid HS, Al-Qadhi MN (2011) Enterobiasis and its relationship with enuresis among one of orphanage care children in Baghdad-Iraq. Iraq Journal Of Science 52: 394-399. Link: https://bit.ly/2V0TOhh

\section{Discover a bigger Impact and Visibility of your article publication with}

Peertechz Publications

\section{Highlights}

* Signatory publisher of ORCID

* Signatory Publisher of DORA (San Francisco Declaration on Research Assessment)

* Articles archived in worlds' renowned service providers such as Portico, CNKI, AGRIS, TDNet, Base (Bielefeld University Library), CrossRef, Scilit, J-Gate etc.

* Journals indexed in ICMJE, SHERPA/ROMEO, Google Scholar etc.

* OAI-PMH (Open Archives Initiative Protocol for Metadata Harvesting)

* Dedicated Editorial Board for every journa

* Accurate and rapid peer-review process

* Increased citations of published articles through promotions

* Reduced timeline for article publication

Submit your articles and experience a new surge in publication services

(https://www.peertechz.com/submission).

Peertechz journals wishes everlasting success in your every endeavours.

Copyright: @ 2021 Etemadi S, et al. This is an open-access article distributed under the terms of the Creative Commons Attribution License, which permits unrestricted use, distribution, and reproduction in any medium, provided the original author and source are credited.

Citation: Etemadi S, Hosniehoseini (2021) Study of the role of IQ in children with Enterobius vermicularis infestation compared to healthy children. Open J Pediatr Child Health 6(1): 043-045. DOI: https://dx.doi.org/10.17352/ojpch.000036 